Использование левосимендана при лечении нейрогенной стрессорной кардиомиопатии у пациентки с субарахноидальным кровоизлиянием (клиническое наблюдение)

А. А. Полупан*, Т. Ф. Табасаранский, А. С. Хейреддин, И. А. Савин, О. М. Зеленкова, Я. В. Савченко, Т. М. Бирг, А. А. Пашин, А. А. Сычев, А. И. Баранич, О. Б. Белоусова

Национальный Медицинский Исследовательский Центр нейрохирургии им. Н. Н. Бурденко Минздрава России

Россия,125047, Москва, 4-я Тверская-Ямская, д. 16

\title{
The Use of Levosimendan in the Treatment of Neurogenic Stress Cardiomyopathy in a Patient with Nontraumatic Subarachnoid Hemorrhage (Case Report)
}

\author{
Aleksandr A. Polupan, Togrul F. Tabasarankiy, Ali S. Kheireddin, Ivan A. Savin, \\ Olga M. Zelenkova, Yan V. Savchenk,, Tatiana M. Birg, Anton A. Pashin, \\ Aleksandr A. Sychev, Anastasia I. Baranich, Olga B. Belousova
}

N. N. Burdenko National Medical Research Center of Neurosurgery, Ministry of Health of Russia 16 Tverskaya-Yamskaya $4^{\text {th }}$ Str., 125047 Moscow, Russia

\begin{abstract}
Для цитирования: А. А. Полупан, Т. Ф. Табасаранский, А. С. Хейреддин, И. А. Савин, О. М. Зеленкова, Я. В. Савченко, Т. М. Бирг, А. А. Пашин, А. А. Сычев, А. И. Баранич, О. Б. Белоусова. Использование левосимендана при лечении нейрогенной стрессорной кардиомиопатии у пациентки с субарахноидальным кровоизлиянием (клиническое наблюдение). Общзая реаниматология. 2021; 17 (4): 22-28. https://doi.org/10.15360/1813-9779-2021-4-22-28 [На русск. и англ.]

For citation: Aleksandr A. Polupan, Togrul F. Tabasarankiy, Ali S. Kheireddin, Ivan A. Savin, Olga M. Zelenkova, Yan V. Savchenk,, Tatiana M. Birg, Anton A. Pashin, Aleksandr A. Sychev, Anastasia I. Baranich, Olga B. Belousova. The Use of Levosimendan in the Treatment of Neurogenic Stress Cardiomyopathy in a Patient with Nontraumatic Subarachnoid Hemorrhage (Case Report). Obshchaya Reanimatologiya = General Reanimatology.2021; 17 (4):22-28. https://doi.org/10.15360/1813-9779-2021-4-22-28 [In Russ. and Engl.]

\section{Резюме}

Представили наблюдение кардиогенного шока вследствие нейрогенной стрессовой кардиомиопатии (НСКМП) у пациентки с нетравматическим субарахноидальным кровоизлиянием вследствие разрыва артериальной аневризмы правой перикаллезной артерии. В связи с рефрактерным к катехоламинам течением шока приняли решение об использовании левосимендана под расширенным гемодинамическим контролем, включающим в себя транспульмональную термодилюцию и эхокардиографию. На фоне терапии отмечали улучшение сократительной функции сердца, снижение потребности в катехоламинах. Полной стабилизации гемодинамики достигли к 5-м суткам. В обсуждении рассмотрели наблюдения лечения стрессовой кардиомиопатии с использованием левосимендана, представленные в литературе.
\end{abstract}

Ключевые слова: нейрогенная кардиомиопатия; субарахноидальное кровоизлияние; левосимендан; нейрогенный отек легких

Конфликт интересов. Авторы заявляют об отсутствии конфликта интересов.

\section{Summary}

We present a case of cardiogenic shock due to neurogenic stress cardiomyopathy (NSC) in a patient with nontraumatic subarachnoid hemorrhage caused by a ruptured aneurysm of the right pericallosal artery. Due to the catecholamine-resistant shock, levosimendan was administered under advanced hemodynamic control, including transpulmonary thermodilution and echocardiography. This resulted in an improved cardiac contractility and reduced demand for catecholamines. Full stabilization of hemodynamic parameters was achieved by day 5 . In the discussion section we reviewed available published case reports of using levosimendan in stress cardiomyopathy treatment.

Keywords: neurogenic cardiomyopathy; subarachnoid hemorrhage; levosimendan; neurogenic pulmonary edema

Conflict of Interest. The authors declare no conflict of interest.

DOI:10.15360/1813-9779-2021-4-22-28

Адрес для корреспонденции:

Александр Александрович Полупан

E-mail: Polupan@yandex.ru
Correspondence to:

Aleksandr A. Polupan*

E-mail: Polupan@yandex.ru 


\section{Введение}

Нейрогенная стрессовая кардиомиопатия (НСКМП) представляет собой обратимую дисфункцию миокарда с выраженным нарушением систолической функции левого желудочка (ЛЖ), развивающуюся на фоне острого повреждения головного мозга, чаще всего на фоне нетравматического субарахноидального кровоизлияния (САК) [1]. Данное осложнение встречается в 20-30\% случаев разрывов артериальных аневризм головного мозга и, как правило, развивается в течение первых 72 часов после кровоизлияния [2, 3]. Классической триадой НСКМП служат нарушение сократимости ЛЖ, электрокардиографические (ЭКГ) изменения (инверсия зубца Т, элевация или депрессия сегмента ST, удлинение интервала QT) и повышение маркеров повреждения миокарда при отсутствии атеросклеротического поражения коронарных артерий [4]. Выраженность поражения миокарда при САК может варьировать от бессимптомных изменений по данным эхокардиографии (ЭХО-КГ) и ЭКГ при минимальном повышении кардиоспецифических ферментов до выраженной левожелудочковой недостаточности, вплоть до развития отека легких и кардиогенного шока [5].

Патогенез НСКМП при аневризматических САК изучен недостаточно. Основная роль отводится гиперактивации симпатоадреналовой системы. В острейшем периоде САК развивается выраженная внутричерепная гипертензия, симпатоадреналовая гиперактивация в этом случае является компенсаторным механизмом, направленным на повышение сердечного выброса (CB) и артериального давления для поддержания адекватной церебральной перфузии. Повышенная активность симпатической нервной системы запускает биохимический каскад, одним из следствий которого является перегрузка кардиомиоцитов кальцием, приводящая к чрезмерному сокращению кардиомиоцитов, истощению запаса высокоэнергетических фосфатов, развитию митохондриальной дисфункции и, в конечном счете, к возникновению, структурньх изменений миокарда [6].

В пользу того факта, что симпатическая гиперактивация является основным пусковым фактором развития НСКМП свидетельствуют данные исследований на животных, в которых было показано, что десимпатизация сердца предотвращает развитие миокардиальной дисфункции при экспериментальном САК. Также в клинических исследованиях было продемонстрировано, что у пациентов с НСКМП на фоне САК отмечалось повышение концентрации катехоламинов в плазме крови и их метаболитов в моче [7].

\section{Introduction}

Neurogenic stress cardiomyopathy (NSC) is a reversible myocardial dysfunction with severe impairment of left ventricular (LV) systolic function developing in acute brain injury, most often due to the non-traumatic subarachnoid hemorrhage (SAH) [1]. This complication occurs in $20-30 \%$ of ruptured cerebral arterial aneurysms and usually develops during the first 72 hours after hemorrhage $[2,3]$. The classic triad of NSC includes impaired LV contractility, electrocardiographic (ECG) changes (T-wave inversion, ST-segment elevation or depression, QT prolongation) and elevated markers of myocardial damage in the absence of atherosclerotic coronary artery lesions [4]. The severity of myocardial damage in SAH can vary from asymptomatic changes found on echocardiography and ECG with minimal elevation of cardiac enzymes to severe left ventricular failure, up to pulmonary edema and cardiogenic shock [5].

The pathogenesis of NSC in aneurysmal SAH is poorly understood. The main role of NSC is given to sympathetic hyperactivity. In the earliest phase of SAH, a severe intracranial hypertension develops; the ensuing sympathetic hyperactivation is a compensatory mechanism aimed at increasing cardiac output (CO) and blood pressure to maintain adequate cerebral perfusion. The increased sympathetic activity triggers a biochemical cascade, resulting in calcium overload of cardiomyocytes, causing excessive contraction of cardiomyocytes, depletion of high-energy phosphate stores, mitochondrial dysfunction and, finally, myocardial structural changes [6].

Animal experiments have shown that cardiac sympathetic denervation prevents myocardial dysfunction in experimental $\mathrm{SAH}$, which suggests the leading role of sympathetic hyperactivation as a trigger factor for NSC development. The clinical studies also demonstrated that in patients with NSC with underlying SAH, increased levels of plasma catecholamines and urine catecholamine metabolites were observed [7].

Adrenergic agonists commonly used to maintain CO in cardiogenic shock are often ineffective in NSC due to the underlying sympathetic hyperactivity. Currently, there is no consensus on the drug of choice to maintain the $\mathrm{CO}$ and, consequently, systemic and cerebral perfusion in NSC. This paper reports a case of successful use of levosimendan for the treatment of cardiogenic shock in NSC developed in a patient with an acute SAH due to right pericallosal artery aneurysm rupture.

\section{Clinical Case}

Female patient P., 34 years old, was admitted to the Burdenko Neurosurgery Center on the first day after SAH due to rupture of aneurysm of the right pericallosal ar- 
Адреномиметики, традиционно используемые для поддержания CВ при кардиогенном шоке, в случае НСКМП зачастую оказываются неэффективными, так как в основе патогенеза данного состояния лежит адренергическая гиперстимуляция. В настоящее время нет единого мнения о препарате выбора для поддержания СВ и, соответственно, системной и церебральной перфузии при НСКМП. В данной статье представили наблюдение успешного использования левосимендана для лечения кардиогенного шока, развившегося на фоне НСКМП у пациентки с острым САК вследствие разрыва аневризмы правой перикаллезной артерии.

\section{Клиническое наблюдение}

Пациентка П., 34 лет поступила в центр нейрохирургии им. акад. Н. Н. Бурденко в первые сутки после САК вследствие разрыва артериальной аневризмы правой перикаллезной артерии. При поступлении уровень бодрствования соответствовал оглушению (13 баллов по шкале комы Глазго (ШКГ)). Среди клинических проявлений отмечали менингиальную симтоматику в виде выраженной ригидности затылочных мышц, очагового неврологического дефицита не было. В день поступления было выполнили клипирование шейки аневризмы правой перикаллезной артерии в условиях ее разрыва с установкой наружного вентриклуярного дренажа в передний рог левого бокового желудочка (рис. 1).

Трахею экстубировали в раннем послеоперационном периоде. На вторые сутки после операции у пациентки развилась клиническая картина острой сердечной недостаточности, осложненной отеком легких. В связи с развившейся на этом фоне гипоксемией начали искусственную вентиляцию легких (ИВЛ). В связи с гемодинамической нестабильностью назначили норэпинефрин в дозе

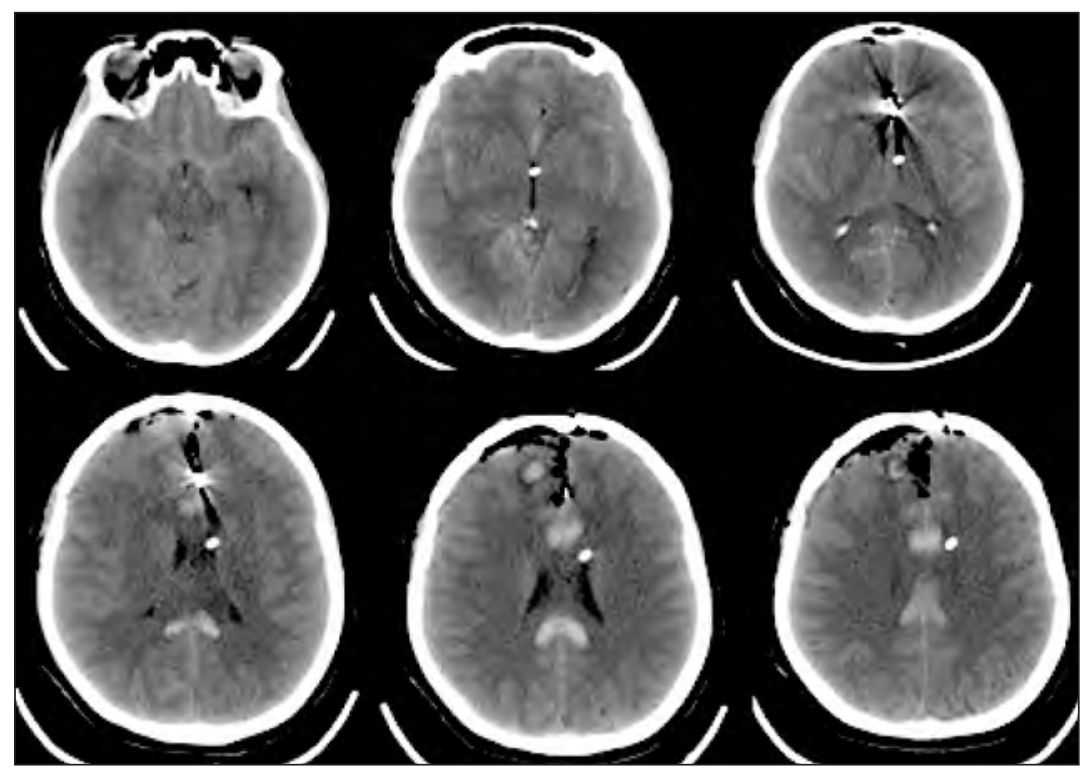

Рис. 1. Послеоперационная КT.

Fig. 1. Brain computed tomography performed post surgery. tery. On admission, the level of consciousness corresponded to mild brain injury (13 points on the Glasgow Coma Scale (GCS)). The clinical manifestations included meningeal signs such as severe nuchal rigidity, however, there was no focal neurological deficit. On the day of admission, clipping of the ruptured right pericallosal artery aneurysm was performed and an external ventricular drainage into the anterior horn of the left lateral ventricle was placed (Fig. 1).

The patient was extubated in the early postoperative period. On day 2 after surgery, the patient developed acute heart failure complicated by pulmonary edema. Due to hypoxemia, the mechanical lung ventilation was started. In view of unstable hemodynamic parameters, norepinephrine $0.2 \mathrm{mcg} / \mathrm{kg} / \mathrm{min}$ was administered to maintain the cerebral perfusion pressure at $60-80 \mathrm{~mm}$ $\mathrm{Hg}$. On echocardiography, minor dilatation of heart chambers, no obvious areas of hypokinesia, and a moderately reduced global cardiac contractility were revealed. In the following hours, the heart failure worsened, which required titration of norepinephrine infusion rate up to $0.5 \mathrm{mcg} / \mathrm{kg} / \mathrm{min}$. Echocardiogram showed left heart dilatation, increased left ventricular end-diastolic volume (LVEDV) to $110 \mathrm{ml}$, LV basal akinesia, reduced ejection fraction (EF) down to $32 \%$, severe mitral regurgitation, mild pulmonary artery regurgitation, while the estimated pulmonary artery pressure (PAP) was $38 \mathrm{~mm} \mathrm{Hg}$. ECG showed nonspecific ST-segment changes (Fig. 2). Laboratory tests have shown increased troponin I level $(2 \mathrm{ng} / \mathrm{ml})$.

Considering the serious hemodynamic decompensation, an advanced hemodynamic monitoring using PiCCO system (Phillips IntelliVue MP 60 cardiac monitor with M1012A cardiac output module) was started. A decrease in cardiac index (CI) down to $1.88 \mathrm{l} / \mathrm{min} \times \mathrm{m}^{2}$ was recorded. Due to the significantly impaired cardiac contractility, we started the inotropic support with levosimendan. After a loading dose $(6 \mu \mathrm{g} / \mathrm{kg})$, there was a slight increase in SI (up to $2.11 \mathrm{l} / \mathrm{min} \times \mathrm{m}^{2}$ ) and an increase in EF up to $40 \%$ according to echocardiography. At the same time, the akinesia of basal segments persisted, and the increase in stroke volume (SV) and EF was ensured by intensified contractility of intact apical sections of the LV. Levosimendan infusion was continued for 24 hours at the rate of $0.1 \mu \mathrm{g} / \mathrm{kg} / \mathrm{min}$. The changes in main hemodynamic parameters are shown in the Table. Levosimendan infusion resulted in gradual increase of the heart contractile function and decrease of peripheral vascular resistance. The rate of norepinephrine infusion was decreased in parallel. After levosimendan infusion was terminated, hemodynamic stabilization continued. Norepinephrine infusion was stopped on day 5, SI reached the lower limit of normal values and was $3.26 \mathrm{l} / \mathrm{min} \times \mathrm{m}^{2}$. The echocardiography performed on day 5 showed a significant improvement of myocardial contractile function, EF was 59\%, although mild hypokinesia of LV basal seg- 
0,2 мкг/кг/мин для поддержания церебрального перфузионного давления (ЦПД) на уровне 60-80 мм рт. ст. При ЭХО-КГ выявили незначительное расширение камер сердца, без явных зон гипокинезии, с умеренным снижением глобальной сократительной функции. В последующие часы отмечали нарастание сердечно-сосудистой недостаточности, что потребовало постепенного увеличения скорости инфузии норэпинефрина до 0,5 мкг/кг/мин. При повторной ЭХО-КГ выявили дилатацию левых отделов сердца, увеличение конечно-диастолического объема левого желудочка (КДО

ЛЖ) до 110 мл, акинезию базальных отделов ЛЖ, снижение фракции выброса (ФВ) до 32\%, выраженную митральную регургитацию, регургитацию на легочной артерии 1 степени, рассчетное давление в легочной артерии (ДЛА) - 38 мм рт. ст. На ЭКГ - неспецифические изменения сегмента ST (рис. 2). Лабораторно - повышение концентрации тропонина І до 2 нг/мл.

Учитывая выраженную гемодинамическую нестабильность, начали расширенный гемодинамический мониторинг с использованием системы РіССО (Кардиомонитор Phillips IntelliVue MP 60 с модулем для измерения сердечного выброса M1012А). Выявили снижение сердечного индекса (СИ) до 1,88 л/мин/м². Учитывая значимое нарушение сократительной функции сердца, начали инотропную поддержку левосименданом. После введения нагрузочной дозы (6 мкг/кг) отмечали некоторое увеличение СИ (до 2,11 л/мин $\left.\times \mathbf{M}^{2}\right)$ и увеличение ФВ до $40 \%$ по данным ЭХО-КГ. При этом акинезия базальных сегментов сердца сохранялась, а увеличение ударного объема (УО) и ФВ обеспечивалось усилением сократимости интактных верхушечных отделов ЛЖ. Инфузию левосимендана продолжили в течение суток со скоростью 0,1 мкг/кг/мин. Динамику основных гемодинамических показателей представили в таблице.

На фоне инфузии левосимендана отмечали постепенное повышение сократительной функции сердца и снижение периферического сосудистого ments persisted, heart chamber sizes returned to normal values (LVEDV was $90 \mathrm{ml}$ ), minimal mitral regurgitation was still observed.

Clinical improvement was also noted, and on day 10 the ventilation was discontinued, and on day 14 the patient was transferred from the ICU. On day 30 post surgery, the patient was discharged from the neurosurgery center without neurological deficits. The echocardiography prior to discharge showed minor left ventricular dilatation, no areas of hypo- and akinesia, and EF reaching $62 \%$.

On follow-up examination three months after discharge, the patient was stable with no symptoms. Echocardiographic parameters were within normal references. Myocardial contractility was normal with EF 69\%.

\section{Discussion}

The inotropic effect of levosimendan is based on sensitization of contractile proteins of cardiac myocytes to calcium. Unlike adrenergic inotropic drugs, levosimendan does not cause calcium overload of cardiomyocytes and does not increase myocardial energy demand [11].

The pharmacological profile of levosimendan makes it a promising drug for the treatment of NSC associated with SAH. There are no large studies on the use of levosimendan in NSC, the data on its efficacy are limited and based on case reports.

\section{Значения показателей в различное время.}

Main cardiac parameters of the patient at various time points.

\begin{tabular}{|c|c|c|c|c|c|c|c|c|}
\hline \multirow[t]{4}{*}{ Parameter } & \multicolumn{8}{|c|}{ Day } \\
\hline & \multirow{3}{*}{ Baseline } & \multicolumn{3}{|l|}{$\mathbf{1}$} & \multirow{2}{*}{\multicolumn{2}{|c|}{$\begin{array}{c}2 \\
\text { Measurement }\end{array}$}} & \multirow[t]{3}{*}{3} & \multirow[t]{3}{*}{5} \\
\hline & & After the loa- & 3 hours & 13 hours & & & & \\
\hline & & ding dose & of infusion & of infusion & First & Second & & \\
\hline$\overline{\mathrm{CI}, \mathrm{l} / \mathrm{min} / \mathrm{m}^{2}}$ & 1.88 & 2.11 & 2.66 & 2.88 & 2.73 & 2.71 & 2.23 & 3.26 \\
\hline Stroke index, $\mathrm{ml} / \mathrm{m}^{2}$ & 19.8 & 21.7 & 29.9 & 35.1 & 24.4 & 28.8 & 26.5 & 32.9 \\
\hline SVRI, dyn $\times \mathrm{s} \times \mathrm{cm}^{-5} / \mathrm{m}^{2}$ & 3871 & 3489 & 2613 & 2333 & 2222 & 2596 & 2834 & 2085 \\
\hline EF, \% & 32 & 40 & 46 & & 45 & & 52 & 59 \\
\hline LVEDV, ml & 110 & 108 & 105 & & 104 & & 98 & 90 \\
\hline Norepinephrine dose, $\mathrm{mg} / \mathrm{kg} / \mathrm{min}$ & 0.5 & 0.5 & 0.3 & 0.3 & 0.3 & 0.2 & 0.1 & 0.1 \\
\hline Troponin I, ng/ml & & & 2 & & 1.4 & & 0.5 & \\
\hline
\end{tabular}

Note. CI — cardiac index; SVRI — systemic vascular resistance index; EF — ejection fraction; LVEDV — left ventricular enddiastolic volume.

Примечание. Day — сутки; baseline — исходно; after the loading dose - после нагруз. дозы; ... hours of infusion — через ... часа инфузии; measurement - измерение; first/second - первое/второе; СI — CИ; stroke index — УИ; SVRI — ИССС; EF — ФВ; LVEDV — КдО лж; norepinephrine dose - доза норэпинефрина. 
сопротивления. Параллельно с этим снижали скорость инфузии норэпинефрина. После прекращения инфузии левосимендана продолжалась стабилизация гемодинамики. Инфузию норэпинефрина прекратили на 5-е сутки, СИ при этом достиг нижней границы нормы и составлял 3,26 л/мин/м². По данным контрольной ЭХО-КГ, выполненной на 5-е сутки, сократительная функция миокарда существенно улучшилась, ФВ составила 59\%, хотя сохранялась легкая гипокинезия базальных отделов ЛЖ, размеры камер сердца вернулись к нормальным значениям (КДО ЛЖ — 90 мл), сохранялась минимальная митральная регургитация.

Клинически также отмечали положительную динамику, на 10-е сутки прекратили ИВЛ, на 14-е сутки пациентку перевели из ОРИТ. На 30 -е сутки после операции пациентку выписали из центра нейрохирургии без неврологического дефицита в удовлетворительном состоянии. На контрольной ЭХОКГ перед выпиской отмечали незначительную дилатацию левого желудочка, зон гипо- и акинезии выявлено не было, $\Phi$ В=62\%.

При контрольном осмотре через три месяца после выписки из стационара состояние пациентки удовлетворительное, жалоб нет. При ЭХО-КГ размеры камер сердца в пределах нормы. Нарушений сократительной функции миокарда нет, $\Phi \mathrm{B}=69 \%$.

\section{Обсуждение}

Инотропный эффект левосимендана основан на сенсибилизации сократительных белков кардиомиоцитов к кальцию. В отличие от адренергических инотропных препаратов, левосимендан не вызывает кальциевую перегрузку кардиомиоцитов и не повышает энергетические потребности миокарда [11].

Фармакологический профиль левосимендана делает его перспективным препаратом для лечения НСКМП у пациентов с САК. Больших исследований, посвященных изучению применения левосимендана при НСКМП в настоящее время нет, данные об его эффективности ограничены рядом описанных клинических случаев.

Stefano Busani и соавторы описали клинический случай развития кардиогенного шока и отека легких после эндоваскулярной эмболизации аневризмы у 38-летней женщины с массивным паренхиматозно-субархноидальным кровоизлиянием с прорывом в желудочковую систему вследствие разрыва аневризмы левой задней нижней мозжечковой артерии [8]. По данным мониторинга гемодинамики с помощью катетера Сван-Ганца, отмечалось значимое снижение СИ при одновременном повышении давления заклинивания легочных капилляров (ДЗЛК), что подтверждало кардиогенный генез шока. Также по данным трансторакальной ЭХО-КГ отмечалось снижение ФВ до 20\%. На фоне использования дофамина, норэпинефрина, добутамина добиться
Busani et al. reported a clinical case of cardiogenic shock and pulmonary edema after endovascular aneurysm embolization in a 38-year-old woman with massive subarachnoid hemorrhage with ventricular spread due to the ruptured left posterior inferior cerebellar artery aneurysm [8]. According to hemodynamic monitoring with SwanGanz catheter, there was a significant decrease in SI with a simultaneous increase in pulmonary capillary wedge pressure (PCWP) suggesting the cardiac origin of shock. Also, the transthoracic echocardiogram revealed reduced EF (20\%). The use of dopamine, norepinephrine, dobutamine did not improve the hemodynamic parameters, severe hypotension and progressive deterioration of pulmonary gas exchange parameters persisted. Due to lack of effect of the common inotropic agents, levosimendan infusion was started. Eight hours after levosimendan infusion was started, SI increased from 1.7 to $2.6 \mathrm{~L} / \mathrm{min} \times \mathrm{m}^{2}$, PCWP decreased from 20 to $10 \mathrm{~mm} \mathrm{Hg}$. The EF increased up to $35-40 \%$. There was a gradual normalization of the gas exchange function of the lungs. On day 7 , the patient was extubated and discharged from the intensive care unit without neurological deficit.

Other authors (Papanikolaou et al., 2014) reported two cases of NSC after SAH and microsurgical clipping of aneurysms, which were associated with severe hemodynamic instability. Early use of levosimendan allowed to stabilize the arterial and cerebral perfusion pressures [9]. Both patients had a critical decrease of EF (less than 20\%) and arterial hypotension resistant to high doses of norepinephrine. Echocardiographic pattern corresponded to that of the patient described in our case and included left heart dilatation, severe basal akinesia, compensatory hypercontractility of the apex. In both cases, levosimendan infusion allowed to rapidly increase the EF above $35 \%$ and achieve hemodynamic stabilization. On day 3, both patients showed complete normalization of cardiac function.

A clinical case presented by Taccone et al. describes the successful use of levosimendan to increase the $\mathrm{CO}$ and improve organ blood flow in a patient with NSC and underlying SAH, whose hemodynamic changes were resistant to norepinephrine, dobutamine and milrinone [10].

\section{Conclusion}

Despite the fact that NSC develops in no less than a quarter of patients with SAH, clinically significant acute heart failure and cardiogenic shock are not so frequent. To date, only anecdotal reports on the successful use of levosimendan for the treatment of cardiogenic shock in patients with SAH. Critical reduction of $\mathrm{CO}$, catecholamine-resistant hypotension, hypoxemia with refractory pulmonary edema can serve as factors of secondary 
улучшения гемодинамических показателей не удавалось, сохранялась выраженная артериальная гипотензия и прогрессивно ухудшались показатели газообменой функции легких. В связи с неэффективностью используемых инотропных агентов было принято решение о начале инфузии левосимендана. Через 8 часов после начала инфузии левосимендана отмечалось повышение СИ с 1,7 до 2,6 л/мин/ м $^{2}$, снижение ДЗЛК с 20 до 10 мм рт. ст. ФВ по данным ЭХО-КГ выросла до 35-40\%. Отмечалась постепенная нормализация газообменной функции легких. На 7-е сутки трахея была экстубирована и пациентку перевели из отделения реанимации без неврологического дефицита.

Другими авторами (Papanikolaou et al. 2014) было описано два случая НСКМП после САК и микрохирургического клипирования аневризм, что сопровождалось выраженной гемодинамической нестабильностью. Раннее использование левосимендана позволило добиться стабилизации артериального и церебрального перфузионного давлений [9]. У обеих пациенток отмечались критическое снижение ФВ (менее 20\%) и артериальная гипотензия, рефрактерная к высоким дозам норэпинефрина. ЭХО-КГ картина соответствовала таковой у пациентки, из описанного нами случая: дилатация левых отелов сердца, выраженный акинез базальных отделов, компенсаторная гиперконтрактильность верхушки. В обоих случаях инфузия левосимендана позволила быстро повысить ФВ выше 35\% и добиться стабилизации гемодинамики. На 3-и сутки у обеих пациенток отмечалось полная нормализация сердечной функции.

\section{Литература}

1. ZaroffJ.G., Rordorf G.A., Ogilvy C.S., Picard M.H. Regional patterns of left ventricular systolic dysfunction after subarachnoid hemorrhage: evidence for neurally mediated cardiac injury. J Am Soc Echocardiogr. 2000; 13: 774-779. DOI: 10.1067/mje.2000.105763

2. Naidech A.M., Kreiter K.T., Janjua N., Ostapkovich N.D., Parra A. Commichau C., Fitzsimmons B-F.M., Connolly E.S., Mayer S.A. Cardiac troponin elevation, cardiovascular morbidity, and outcome after subarachnoid hemorrhage. Circulation. 2005; 112: 2851-2856. DOI: $10.1067 / \mathrm{mje} .2000 .105763$

3. Bybee K.A., Prasad A. Stress-related cardiomyopathy syndromes. Circulation. 2008; 118 (4): 397-409. DOI: 10.1161/circulationaha.106.677625

4. Elrifai A.M., Bailes J.E., Shih S.R., Dianzumba S., Brillman J. Characterization of the car- diac effects of acute subarachnoid hemorrhage in dogs. Stroke 1996; 27: 737-741. DOI: 10.1161/01.str.27.4.737

5. Lyon A.R., Rees P.S., Prasad S., Poole-Wilson P.A., Harding S.E. Stress (takotsubo) cardiomyopathy a novel pathophysiological hypothesis to explain catecholamine-induced acute myocardial stunning. $\mathrm{Nat}$ Clin Pract Cardiovasc Med. 2008; 5: 22-29. DOI: 10.1038/ ncpcardio1066

6. Baroldi G., Mittleman R.E., Parolini M., Silver M.D., Fineschi V. Myocardial contraction bands. Definition, quantification and significance in forensic pathology. Int J Legal Med. 2001; 115: 142-151. PMID: 11775016 DOI: $10.1007 /$ s004140100229

7. Grad A., Kiauta T., Osredkar J. Effect of elevated plasma norepinephrine on electro- cardiographic changes in subarachnoid hemorrhage. Stroke. 1991; 22: 746-749. DOI: 10.1161/01.str.22.6.746

8. Busani S., Rinaldi L., Severino C., Cobelli M., Pasetto A., Girardis M. Levosimendan in cardiac failure after subarachnoid hemorrhage. $J$ Trauma. 2010; 68: E108-10. DOI: 10.1097/ta.0b013e31817c4284

9. Papanikolaou J., Tsolaki V., Makris D., Zakynthinos E. Early levosimendan administration may improve outcome in patients with sub- brain damage and worsen outcomes in patients with SAH. In our case and in the observations described in the literature, the use of levosimendan allowed to rapidly achieve hemodynamic stabilization in cardiogenic shock associated with NSC.

В клиническом случае, представленном Taccone и соавторами, описывается опыт эффективного применения левосимендана для увеличения СВ и улучшения органного кровотока у пациентки с НСКМП на фоне САК, у которой гемодинамические нарушения оказались резистентными к норадреналину, добутамину и милринону [10].

\section{Заключение}

Несмотря на то, что НСКМП развивается не менее, чем у четверти пациентов с САК, клинически значимая острая сердечная недостаточность и кардиогенный шок встречаются не так часто. Таким образом, в настоящее время имеются лишь единичные сообщения об успешном применении левосимендана для лечения кардиогенного шока у пациентов с САК. Критическое снижение СВ, рефрактерная к катехоламинам артериальная гипотензия, гипоксемия на фоне рефрактерного отека легких могут служить факторами вторичного повреждения головного мозга и ухудшать исходы у пациентов с САК. В представленном нами и в описанных в литературе клинических случаях использование левосимендана позволяло быстро добиться стабилизации гемодинамики при кардиогенном шоке на фоне НСКМП.

\section{References}

1. ZaroffJ.G., RordorfG.A., Ogilvy C.S., Picard M.H. Regional patterns of left ventricular systolic dysfunction after subarachnoid hemorrhage: evidence for neurally mediated cardiac injury. JAm Soc Echocardiogr. 2000; 13: 774-779. DOI: 10.1067/mje.2000.105763

2. Naidech A.M., Kreiter K.T., Janjua N., Ostapkovich N.D., Parra A. Commichau C., Fitzsimmons B-F.M., Connolly E.S., Mayer S.A. Cardiac troponin elevation, cardiovascular morbidity, and outcome after subarachnoid hemorrhage. Circulation. 2005; 112: 2851-2856. DOI: $10.1067 / \mathrm{mje} .2000 .105763$

3. Bybee K.A., Prasad A. Stress-related cardiomyopathy syndromes. Circulation. 2008; 118 (4): 397-409. DOI: 10.1161/circulationaha.106.677625

4. Elrifai A.M., Bailes J.E., Shih S.R., Dianzumba S., Brillman J. Characterization of the car- diac effects of acute subarachnoid hemorrhage in dogs. Stroke 1996; 27: 737-741. DOI 10.1161/01.str.27.4.737

5. Lyon A.R., Rees P.S., Prasad S., Poole-Wilson P.A., Harding S.E. Stres (takotsubo) cardiomyopathy-a novel pathophysiological hypothesis to explain catecholamine- induced acute myocardial stunning. Nat Clin Pract Cardiovasc Med. 2008; 5: 22-29. DOI: 10.1038/ncpcardiol066

6. Baroldi G., Mittleman R.E., Parolini M., Silver M.D., Fineschi V. Myocardial contraction bands. Definition, quantification and significance in forensic pathology. Int J Legal Med. 2001; 115: 142-151. PMID: 11775016 DOI: $10.1007 / \mathrm{s} 004140100229$

7. Grad A., Kiauta T., Osredkar J. Effect of elevated plasma norepinep hrine on electro- cardiographic changes in subarachnoid hemorrhage. Stroke. 1991; 22: 746-749. DOI: 10.1161/01.str.22.6.746

8. Busani S., Rinaldi L., Severino C., Cobelli M., Pasetto A., Girardis M. Levosimendan in cardiac failure after subarachnoid hemorrhage. $J$ Trauma. 2010; 68: E108-10. DOI: 10.1097/ta.0b013e31817c4284

9. Papanikolaou J., Tsolaki V., Makris D., Zakynthinos E. Early levosimendan administration may improve outcome in patients with sub- 
arachnoid hemorrhage complicated by acute heart failure. Int J Cardiol. 2014; 176 (3): 1435-1437. DOI: 10.1016/j.ijcard.2014.08.039

10. Taccone F.S., Brasseur A. Vincent J.L., De Backer D. Levosimendan for the treatment of subarachnoid hemorrhage-related cardiogenic shock. Inensive Care Med. 2013; 39 (8): 1497-1498. DOI: 10.1007/s00134-013-2945-5

11. Papp Z., Agostoni P., Alvarez J., Bettex D., Bouchez S., Brito D., Černý V., Comin-Colet J., Crespo-Leiro M.G., Delgado J.F., Edes I., Eremenko A.A., Farmakis D., Fedele F., Fonseca C., Fruhwald S., Girardis M., Guarracino F., Harjola V.-P., Heringlake M., Herpain A., Heunks L.M.A., Husebye T., Ivancan V., Karason K., Kaul S., Kivikko M., Kubica J., Masip J., Matskeplishvili S., Mebazaa A., Nieminen M.S., Oliva F., Papp J.G., Parissis J., Parkhomenko A., Põder P., Pölzl G., Reinecke A., Ricksten S.-E., Riha H., Rudiger A., Sarapohja T., Schwinger R.H.G. Toller W., Tritapepe L., Tschöpe C., Wikström G., von Lewinski D., Vrtovec B., Pollesello P. Levosimendan Efficacy and Safety: 20 Years of SIMDAX in Clinical Use. Cardiovasc Pharmacol. 2020; 76 (1): 4-22. DOI: 10.1097/FJC.0000000000000859

Поступила 28.04.20 arachnoid hemorrhage complicated by acute heart failure. Int J Cardiol. 2014; 176 (3): 1435-1437. DOI: 10.1016/j.ijcard.2014.08.039

10. Taccone F.S., Brasseur A., Vincent J.L. De Backer D. Levosimendan for the treatment of subarachnoid hemorrhage-related cardiogenic shock. Inensive Care Med. 2013; 39 (8): 1497-1498. DOI: 10.1007/s00134-013-2945-5

11. Papp Z., Agostoni P., Alvarez J., Bettex D., Bouchez S., Brito D., Černý V., Comin-Colet J., Crespo-Leiro M.G., Delgado J.F., Édes I., Eremenko A.A., Farmakis D., Fedele F., Fonseca C., Fruhwald S., Girardis M., Guarracino F., Harjola V.-P., Heringlake M., Herpain A., Heunks L.M.A., Husebye T., Ivancan V., Karason K., Kaul S., Kivikko M., Kubica J., Masip J., Matskeplishvili S., Mebazaa A., Nieminen M.S., Oliva F., Papp J.G., Parissis J., Parkhomenko A., Põder P., Pölzl G., Reinecke A. Ricksten S.-E., Riha H., Rudiger A., Sarapohja T., Schwinger R.H.G. Toller W., Tritapepe L., Tschöpe C., Wikström G., von Lewinski D., Vrtovec B., Pollesello P. Levosimendan Efficacy and Safety: 20 Years of SIMDAX in Clinical Use. Cardiovasc Pharmacol. 2020; 76 (1): 4-22. DOI: 10.1097/FJC.0000000000000859

Received 28.04.20 